\title{
FRANJEVCI U SENJU - OD KONVENTUALACA DO OPSERVANATA
}

\author{
Daniel Patafta \\ Katolički bogoslovni fakultet \\ Sveučilište u Zagrebu \\ Vlaška 38 \\ HR 10000 Zagreb \\ d.patafta@yahoo.com
}

UDK: 2-788 (497.5Senj)

Izvorni znanstveni članak

15.09.2019.

Franjevački samostan u Senju osnovan je u 13. stoljeću kada upravitelji grada postaju Krčki knezovi, kasnije Frankopani. Franjevci su u to vrijeme nositelji obnove Crkve i njihova prisutnost u gradovima pokazuje da je određena sredina došla do određenog stupnja urbaniteta. S druge strane, franjevci u gradovima predstavljaju element koji pridonosi razvoju gradskog života u svim sferama. U članku se prati razdoblje od osnivanja franjevačkog samostana u Senju do početka 16. stoljeća. Povijest senjskog franjevačkog samostana prikazana je u kontekstu širih crkvenih i društveno-političkih odnosa na europskoj i lokalnoj razini.

Utjecaj velikaške obitelji Krčkih knezova/Frankopana na širenje franjevaca i prijelaz pojedinih samostana iz konventualskog života u opservantski, u ovom slučaju samostana u Senju, prikazan je kroz procese na razini opće Crkve koji su se odražavali na prostoru srednje i jugoistočne Europe. Stoga je tema rada prikazati kako se u kontekstu društvenopovijesnih okolnosti dogodio prijelaz iz konventulaizma u opservanciju među senjskim franjevcima. Također je valorizirana uloga Krčkih knezova/Frankopana i njihovo pravo patronata nad mjesnom Crkvom kao temeljnih nositelja društvenog i političkog života na velikom prostoru njihove vlasti u kontekstu feudalnih odnosa srednjovjekovne Hrvatske.

Na primjeru samostana u Senju može se vidjeti kako su promjene i procesi kroz tri stoljeća utjecali na ulogu samostana u životu određenog prostora, promjene u samom životu franjevaca koji napuštaju konzervativniji konventualski smjer i prihvaćaju strogo opsluživanje Pravila - opservanciju, utjecaj feudalnih velikaša na crkveni i politički život prostora kojim su vladali, a sve u okviru događanja na općoj europskoj i crkvenoj razini te na prostoru koji je činio neposredno zaleđe njihove državine. Početkom 16. stoljeća i prodorom Osmanlija uništene su sve srednjovjekovne institucije na području frankopanske vlasti. Samostan u Senju preživio je osmanlijska pustošenja i, slabljenjem frankopanskog utjecaja na društvena, politička i crkvena zbivanja na tome prostoru, ušao u razdoblje novoga vijeka.

Ključne riječi: Senj, franjevci, samostan, krčki knezovi/Frankopani, konventualci, opservanti, Bosna Srebrena, Bosna Hrvatska, Osmanlije 


\section{Uvod}

Prisutnost franjevaca na hrvatskom tlu seže u vrijeme osnivača Reda sv. Franje Asiškog. Na Generalnom kapitulu Reda 1219. godine u Asizu osnovana je Provincia Hungariae za područje Ugarsko-hrvatskog kraljevstva. Naime, već je na kapitulu Franjevačkog reda 1217. dogovoreno da se osnuje jedinstvena provincija za Ugarsku i Hrvatsku pod nazivom Provincia Hungariae. Djelovanje te provincije nije sezalo dalje od rijeke Drave. ${ }^{1} \mathrm{U}$ samu Ugarsku franjevci su došli iz Njemačke i osnovali 1229. samostan u Ostrogonu, a 1239. i posebnu Ostrogonsku provinciju. Gotovo istodobno izdvojili su se primorski samostani, oko 1232. ili 1233. godine, u samostalnu Provincia Sclavoniae, S. Seraphini u Dalmaciji. Na kapitulu u Rimu 1239. Ugarska i Ostrogonska provincija bile su ujedinjene u jedinstvenu Provinciae Regni Hungariae, dok su primorski, dalmatinski i istarski samostani ostali u okviru Provinciae Sclavoniae. ${ }^{2}$

Papa Inocent IV. povjerio je 1248. senjskom biskupu Filipu i provincijalu Provinciae Sclavoniae zadaću ispitati pravovjerje bosanskog bana Ninoslava. ${ }^{3}$ Papa Nikola IV. je četiri desetljeća kasnije poslao u Bosnu, odnosno u Mačvu i Srbiju, dva franjevca spomenute provincije. Isti papa je 1291. ovlastio dva franjevca u Bosni da trajno djeluju kao ispitivači krivovjerja, a 1298. papa Bonifacije VIII. proširio je prvo franjevcima Provinciae Sclavoniae pravo inkvizicije na Srbiju, Rašu, Dalmaciju, Hrvatsku, Bosnu, Istru i druge susjedne krajeve. $^{4}$

Franjevci Provinciae Sclavoniae razvili su to inkvizicijsko djelovanje u Bosni napose u prvoj polovici 14. stoljeća jer su tada imali dovoljno članova u četiri kustodije sa dvadeset i tri samostana. ${ }^{5}$ Papa Ivan XXII. je zatim 1324. imenovao provincijala Provinciae Sclavoniae Fabijana iz Motovuna inkvizitorom i na području Hrvatske. ${ }^{6} \mathrm{U}$ tom razdoblju franjevci su se iz Dalmacije proširili na sjeverni dio Jadrana, na kvarnersko otočje i na tlo Hrvatskog primorja. Podigli su samostane na Rabu, na Cresu, u Krku i u Senju.

${ }^{1}$ Usp. M. ŽUGAJ, 1982; S. J. ŠKUNCA, 2006, 21.

${ }^{2}$ Usp. D. FARLATI, 1800, 96; M. ŽUGAJ, 1982; M. ŽUGAJ, 1989, 50-51; V. BELAJ, 1992, 18; V. BELAJ et. al., 2000, 12-18; F. E. HOŠKO, 2000, 18; F. E. HOŠKO, 2001, 20; S. J. ŠKUNCA, 2006, 21.

${ }^{3}$ D. MANDIĆ, 1968, 39.

${ }^{4}$ A. THEINER, 1860, II, 360, 381.

${ }^{5}$ D. MANDIĆ, 1968, 41-43.

${ }^{6}$ D. MANDIĆ, 1968, 25. 


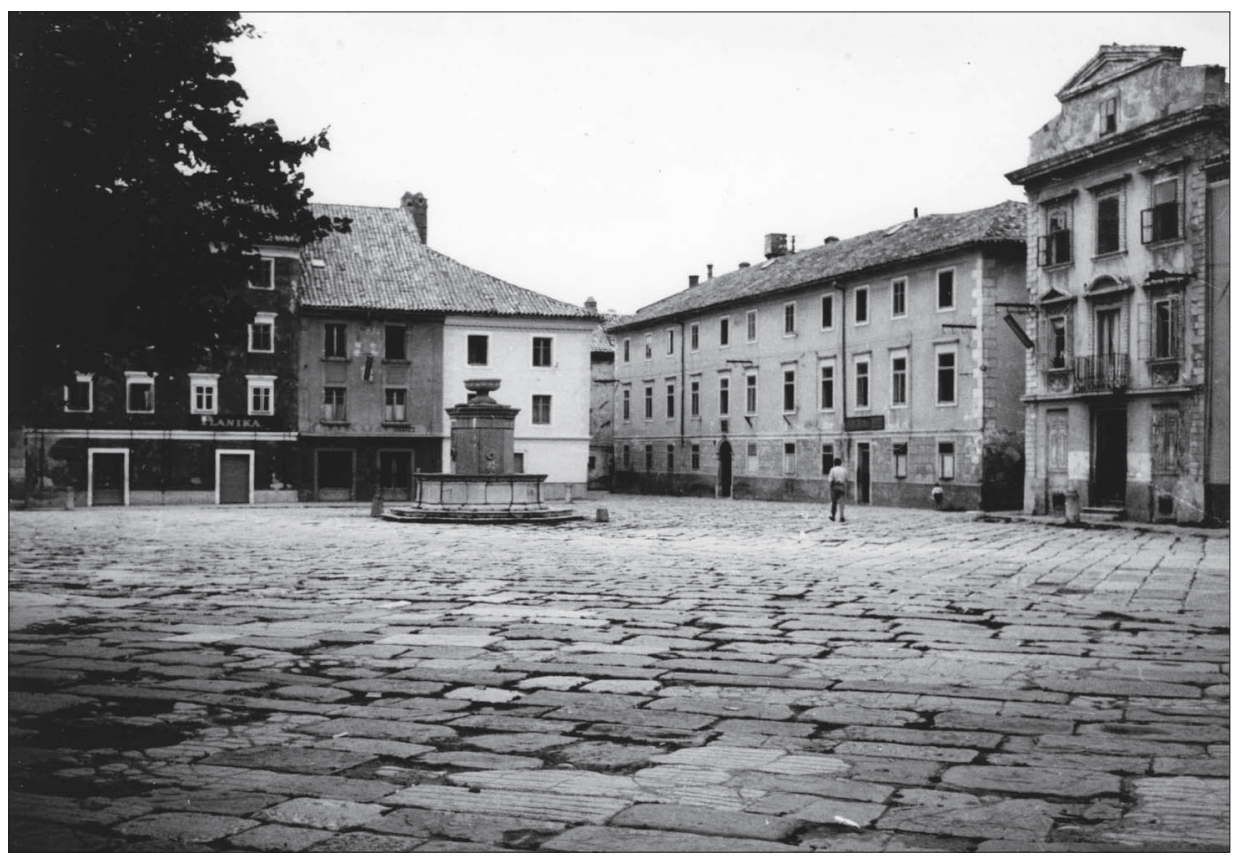

Sl. 1. Franjevački samostan na trgu Cilnica u Senju (izvor: arhiv Gradskog muzeja Senj)

\section{Dolazak franjevaca u Senj i pojava opservancije}

U vrijeme svojega nastanka u 13. stoljeću franjevci su izdanak novoga komunalnog društva koje, razvijajući svoju samosvijest pred Crkvu, stavlja nove izazove na svim područjima njezina djelovanja. Franjevačka povijest srednjega vijeka najvećim dijelom obilježava franjevce kao Red svojstven gradskim sredinama. Prvi samostani u Hrvatskoj nastaju na području dalmatinskih komuna, a od sredine 13. stoljeća, nakon tatarske provale i osnivanja slobodnih kraljevskih gradova, postaju sastavna cjelina gradskog života i na kontinentu Hrvatske. Franjevci se u Senju prvi put spominju 1272. godine. ${ }^{7}$ Njihov dolazak u Senj podudara se s vremenom kada Krčki knezovi 1271. dobivaju upravu nad gradom, a samostan i crkva izgrađeni su izvan grada kao njihova obiteljska zadužbina. ${ }^{8}$

${ }^{7}$ Usp. M. SLADOVIĆ, 1856, 213; T. SMIČIKLAS, 1907, CD, V, 620, 622; M. BOLONIĆ, 1973, 254; M. BOGOVIĆ, 1990, 85.

${ }^{8}$ Usp. D. FARLATI, 1769, IV, 229; M. SLADOVIĆ, 1856, 241; J. FRANČIŠKOVIĆ, $1931,32$. 
Crkva je posvećena 1298. godine, ${ }^{9}$ iako stariji franjevački povjesničari (a zatim od njih taj podatak preuzimaju i drugi) pišu kako su samostan i crkvu sagradili krčki knezovi Leonard i Dujam 1297. godine. ${ }^{10}$ Postoji mogućnost da je senjski biskup Filip i sam bio franjevac, s obzirom na poslanje koje mu je povjerio papa, a možda čak i papin poslanik. ${ }^{11}$ Ovo poslanje pokazuje da je uloga senjskih franjevaca bila puno važnija od lokalnoga značenja. Njihova usmjerenost prema misijskom poslanju u Bosni, koja je povjerena biskupu Filipu, ukazuje i na važnost franjevačke komponente prema misijskom radu u Bosni.

Kada u 14. stoljeću Krčki knezovi potpuno preuzimaju upravu nad Senjom i priključuju ga svojim posjedima, uz pavline postaju veliki zaštitnici franjevaca i bogato daruju njihov samostan. ${ }^{12} \mathrm{U}$ ovoj crkvi pokopan je knez i hrvatskoslavonski ban Ivan (Anž) V. Frankopan, ${ }^{13}$ a 1456. kneginja Izolda (Ižota) d'Este, supruga kneza Stjepana III. Frankopana Modruškog. ${ }^{14}$ Samostan bogato daruju senjski građani i stanovnici širega kvarnerskog područja. ${ }^{15}$ Franjevački samostan u Senju tako postaje bogati i ugledni samostan koji će sve više naginjati prema konzervativnijem načinu življenja redovničkog života, tzv. konventualizmu.

U Senju se, osim javnih natpisa, sačuvalo nešto više od desetak frankopanskih nadgrobnih ploča ili grobnica iz razdoblja od 15. do 17. stoljeća. Puno toga je s vremenom uništeno i u nepovrat izgubljeno. Mramorni reljefi koji su nekoć bili postavljeni na pročelju nove franjevačke crkve u Senju bili su zapravo dijelovi nadgrobnih spomenika knezova Frankopana - prvotno situiranih u starom franjevačkom samostanu izvan grada, a zatim sekundarno iskorišteni kod izgradnje nove crkve. Prema istraživanjima P. Markovića radilo bi se o sarkofazima Nikole IV. i njegova starijeg brata Ivana (Anža) VI. Također, u Senju je sačuvan lijepo izrađen grb knezova Krčkih/Frankopana,

${ }^{9}$ T. SMIČIKLAS, 1909, CD, VII, 303.

${ }^{10}$ Usp. D. FARLATI, 1769, IV, 120; C. PASCONI, 1731, 202; V. KLAIĆ, 1901, 116; J. BURIĆ, 2002, 146-147.

${ }^{11}$ M. BOGOVIĆ, 1998, 60, 78.

${ }^{12}$ Usp. T. SMIČIKLAS, 1913, CD, XI, 584-585; T. SMIČIKLAS, 1914, CD, XII, 216218; T. SMIČIKLAS - M. KOSTRENČIĆ - E. LASZOWSKI, 1915, CD, XIII, 456-457; M. SLADOVIĆ, 1856, 237, 241-243.

${ }^{13}$ I. KUKULJEVIĆ-SAKCINSKI, 1891, 4; V. KLAIĆ, 1901, 188; P. TIJAN, 1931, 32; A. GLAVIČIĆ, 1983-1984, 346, 352; Z. HORVAT, 2002, 81, 82.

${ }^{14}$ V. KLAIĆ, 1901, 241-242.

${ }^{15}$ Usp. T. SMIČIKLAS, 1907, CD, V, 622; T. SMIČIKLAS, 1909, CD, VII, 80-82, 157-158, 212-213; T. SMIČIKLAS, 1913, CD, XI, 203-205; T. SMIČIKLAS - M. KOSTRENČIĆ, 1934, CD, XV, 60-64; T. SMIČIKLAS - M. KOSTRENČIĆ - J. STIPIŠIĆ, 1976, CD, XVI, 54; M. SLADOVIĆ, 1856, 241-244; M. ŽUGAJ, 1989, 233-234. 


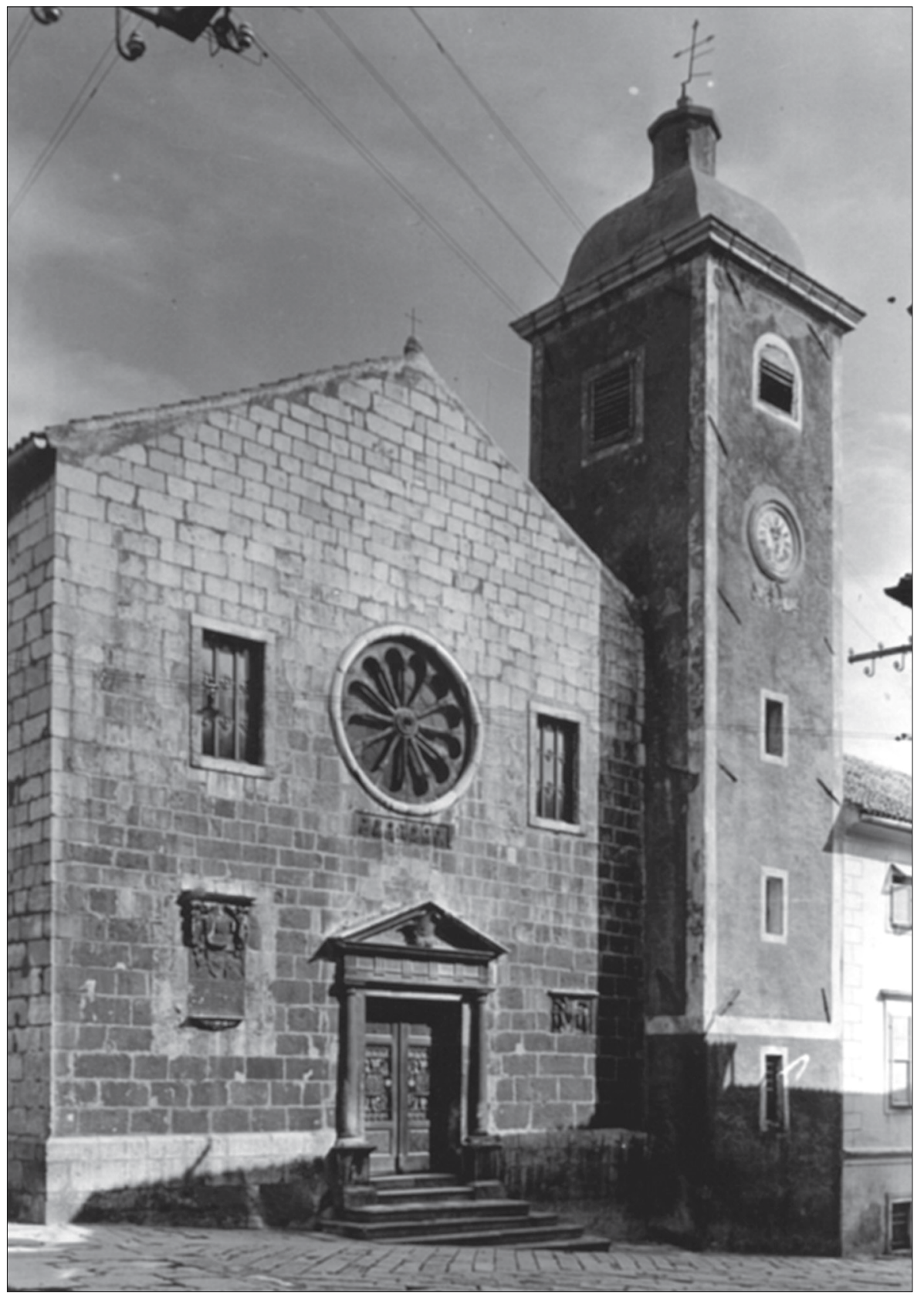

Sl. 2. Pročelje crkve svetog Franje u Senju (izvor: arhiv Gradskog muzeja Senj) 
kombinacija staroga i novoga grba, sa skulpturama lijevo i desno od grba, koji se nalazio na glavnom pročelju crkve sv. Franje. ${ }^{16}$

Kako je Franjevački red rastao i bolje se organizirao, postalo je nužno modificirati strogo pridržavanje onih dijelova Pravila koja se odnose na siromaštvo. Upravo je ovo dovelo do prvih podjela u Redu koje su bile vezane uz interpretaciju i prilagodbu Pravila sv. Franje promijenjenim okolnostima. Dok je jedna strana više naglašavala održavanje duha sv. Franje, a ublažavanje strogih odredaba Pravila, druga strana smatrala je da je taj duh nemoguće održati ako se doslovce ne slijedi Pravilo. Sv. Bonaventura je tijekom svojega generalata (1257. - 1274.) mudro pokušao pomiriti obje struje nalazeći srednji put kojim se ne bi ublažila strogoća Pravila tako da bi sve prilagodbe, a osobito povlastice koje je Red dobio, bile prihvatljive u odnosu na Pravilo. Već u njegovo vrijeme Sveta je stolica dopustila Redu prihvaćati donacije i nasljedstva te posjedovati nekretnina. Pojedinac, u skladu sa zavjetom siromaštva, nije posjedovao ništa, ali je Red sada dobio pravo da se bavi materijalnim pitanjima, pa čak i financijskim. Dobra Reda proglašena su vlasništvom Svete stolice bulom pape Nikole III. Exiit qui seminat od 14. kolovoza 1279. godine. ${ }^{17}$ Papa Ivan XXII. bulom Ad Conditionem od 8. prosinca 1322. prvi se odrekao prava Crkve na posjede Reda Manje braće i vratio ih u njihovo vlasništvo, no to je 1 . studenog 1428. povukao Martin V. i ponovno uspostavio vlasništvo Svete stolice nad dobrima Reda. ${ }^{18}$ Nikola III. imenovao je i upravitelje franjevačkih dobara. Za to su bili izabrani ljudi od povjerenja poznati kao nuntii, procuratores ili kasnije kao syndici. ${ }^{19} \mathrm{Uloga}$ ovih upravitelja bila je nužna kako bi franjevci mogli obdržavati siromaštvo onako kako to traži Pravilo, što se pokazalo nemogućim uzme li se u obzir veliko širenje Reda, napredak znanosti i akumuliranje bogatstva velikih samostana u gradovima.

Tijekom 14. i 15. stoljeća u Franjevačkom redu razvila su se dva smjera poznata pod nazivima konventualizam i opservancija. Reformni pokret opservanata nastao je u razdoblju između 1334. i 1354., a svoju definitivnu formu dobio je oko 1368. godine. Pokret se javio u različitim dijelovima zapadnog kršćanstva i u počecima nije imao jedinstveno usmjerenje i formu. Papa Klement VI. dozvolio je Gentilu iz Spoleta da s drugom braćom živi

${ }^{16}$ Z. HORVAT, 2005, 25-56; P. MARKOVIĆ, 2006, 9-28; T. GALOVIĆ, 2018, 257-278; O. KOSANOVIĆ, 2013, 1-20.

${ }^{17} \mathrm{BF}, 1765$, III, 404.

${ }^{18} \mathrm{BF}, 1889, \mathrm{~V}, 233,486$.

${ }^{19} \mathrm{BF}, 1765$, III, 501. 
izvorno Franjino Pravilo u samotištu Carceri blizu Asiza. ${ }^{20}$ Zbog doticaja s heretičkim pokretom fraticella Generalni kapitul u Asizu zabranio je 1354. novi pokret. Ponovno oživljavanje pokreta započinje 1368. godine s Pavlom od Trinicija. On uz dozvolu generalnog ministra Franjevačkog reda zajedno s grupom braće živi u strogom siromaštvu u samotištu Brugliano. Ubrzo su ovakav oblik života prihvatila i samotišta Carceri, Sv. Damjan, Greccio, Fontecolombo i Poggio Bustone. ${ }^{21}$ Godine 1380. Pavao iz Trinicija imenovan je generalnim vizitatorom (vikarom) za dvanaest samotišta reformnog pokreta u središnjoj Italiji, s dozvolom da može uspostaviti i novicijat. Za njegova nasljednika izabran je Ivan od Stronconia 1414., broj reformiranih zajednica u Italiji popeo se na 34, a 1315. pokretu su pristupili i franjevci iz Porcijunkule. ${ }^{22}$ Svoju unifikaciju i organizirano djelovanje opservancija u Italiji dobila je djelovanjem Bernadina Sijenskog i Ivana Kapistrana, koji su ovaj oblik reforme prenijeli i izvan granica Italije.

Sam pokret u svojim počecima nije bio jedinstven. Oblici opservancije razvili su se neovisno o talijanskom u Portugalu, Španjolskoj, Francuskoj i srednjovjekovnoj Bosni. Ukratko rečeno, bio je to pokret koji je težio otkrivanju franjevačkog identiteta, a javio se u vrijeme i nakon avinjonskog sužanjstva i zapadnog raskola kao dio sveopćega pokreta za obnovu Crkve. Franjevci Bosanske vikarije prigrlili su još u 14. stoljeću opservantski pokret. Najviše je udjela u širenju pokreta među franjevcima u Bosni imao upravitelj Bosanske vikarije Bartol Alvernski. Dok je Bosanska vikarija djelovala misionarski i pastoralno u Bosni, istodobno se zauzimala za ideje franjevačkog opservantskog pokreta. Štoviše, rana i opća razmahanost opservancije u Bosni nameće misao da se u Bosanskoj vikariji opervancija javila neovisno o talijanskoj opservanciji. Dominik Mandić smatra da se opservancija u Bosni razvila neovisno o opservanciji u drugim franjevačkim pokrajinama, ali i prije pojave u tim pokrajinama. ${ }^{23}$ Svakako je opservancija u Bosanskoj vikariji posljedica i zahtjev ozbiljnog nastojanja da se životom po Franjinu idealu podupre misionarska djelatnost. Opservancija u Bosni bila je nužna potreba te djelatnosti jer je upravo ona tražila čistoću franjevačkog evanđeoskog ideala u odnosu prema bosanskim krstjanima.

${ }^{20}$ Usp. F. UGHELLI, 1721, VIII, 701; C. EUBEL, 1886, 56; L. PALOMES, 1897, 258; L. WADDINGUS, 1932, VIII, 103-104.

${ }^{21}$ L. WADDINGUS, 1932, VIII, 209-210; L. PALOMES, 1897, 266-271.

${ }^{22}$ L. WADDINGUS, 1932, VIII, 229; L. PALOMES, 1897, 266-271.

${ }^{23}$ D. MANDIĆ, 1968, 236-237. 


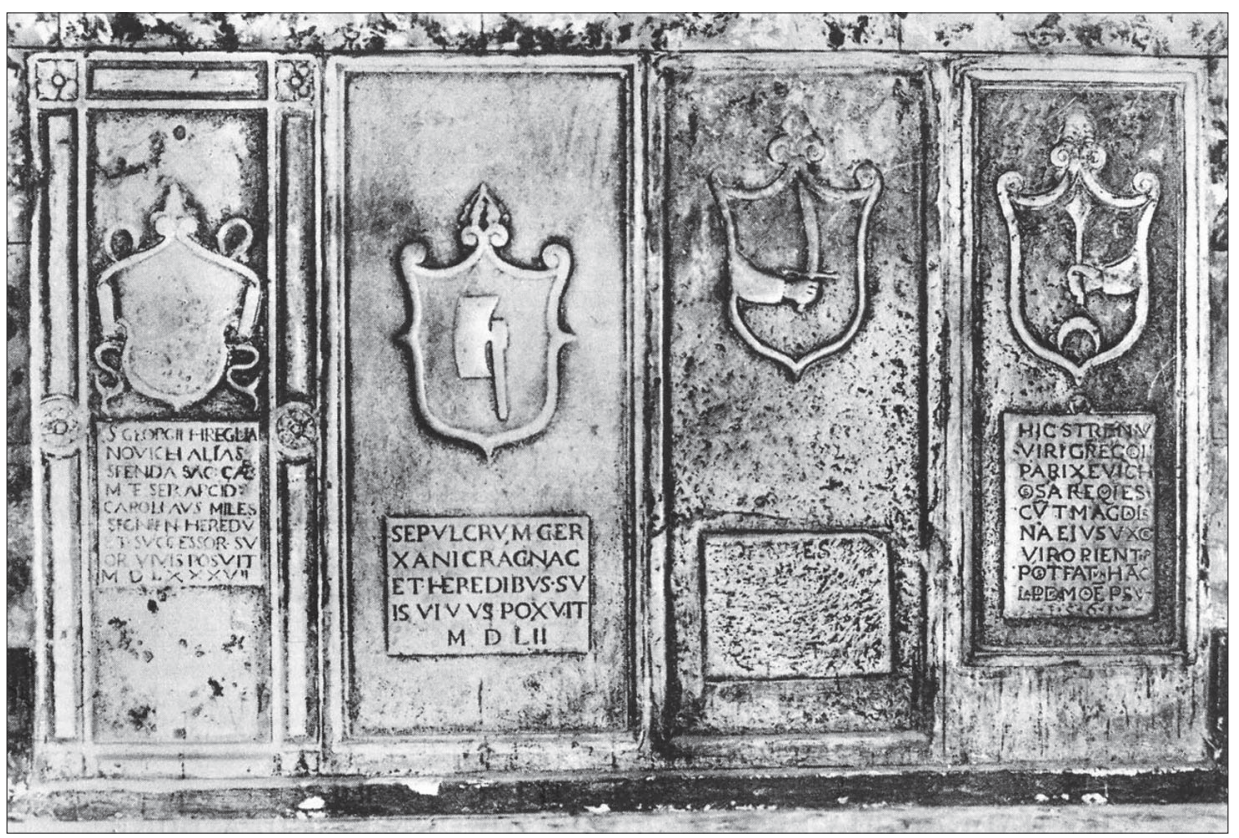

S1. 3. Nadgrobne ploče senjskih uskočkih obitelji, dio inventara crkve svetog Franje (izvor: arhiv Gradskog muzeja Senj)

\section{Bosanska misija i franjevci na frankopanskim posjedima}

Spomenuti razlog širenja franjevaca u Hrvatskoj potpomognut je onodobnim društvenim odnosima, tj. feudalnim društvenim ustrojstvom koje feudalcima pruža, uz gospodarsku moć, i patronat nad crkvenim institucijama. Hrvatsko primorje i njegovo zaleđe je istovjetno s područjem tzv. državine Krčkih knezova ili frankopanske državine. Već je samostan u Krku bio na području vlasti Krčkih knezova. Njihovu vlast je 1193. ugarsko-hrvatski kralj Bela II. proširio na kopno darovavši knezu Bartolu Krčkom kotar Modruš u tek osnovanoj Krbavskoj biskupiji. ${ }^{24}$ Početkom 13. stoljeća Krčki knezovi postaju feudalni gospodari kotara ili župe Vinodol (1225.) koja je također u crkvenom pogledu pod vlašću krbavskog biskupa. ${ }^{25}$ Potkraj tog stoljeća (1271.) i početkom 14. stoljeća (1300.) Krčki knezovi proširuju vlast na grad Senj i na župu Gacku,

${ }^{24}$ V. KLAIĆ, 1901, 43-49; Nada Klaić analizom ključnih dokumenata dolazi do zaključka kako su Krčki knezovi u posjed Modruša i Vinodola došli tek početkom 14. Stoljeća (N. KLAIĆ, 1971, 129-168).

${ }^{25}$ I. ČRNČIĆ, 1867, 96-97. 
a to područje pripada pod jurisdikciju senjskog biskupa. Krčki knezovi su tek oko 1420. stekli župu Bužane i zadržali je u svojoj vlasti do konca 15. stoljeća. ${ }^{26}$ Ta je župa barem najvećim dijelom pripadala pod crkvenu vlast krbavskog ili modruškog biskupa. ${ }^{27}$ Tako od kraja 13. stoljeća pa do konca srednjeg vijeka, krajevi pod feudalnom vlašću različitih grana porodice Krčkih knezova/ Frankopana obuhvaćaju gotovo u cijelosti jurisdikcijsko područje triju biskupija: krčke, senjske i krbavske, a kroz pola stoljeća i četvrte, otočke (1461. -1527.), sa središtem u Otočcu. ${ }^{28}$

Feudalna vlast nije sama po sebi uključivala pravo patronata nad mjesnom Crkvom, pogotovo zato što su nakon 1102. ugarsko-hrvatski kraljevi držali da njima pripada vrhovno i opće patronatsko pravo nad Crkvom na području njihove vlasti, pa su ga oni eventualno povjeravali podređenim velikašima i drugim upravnim tijelima. Tako je kralj Ladislav Kumanac 11. lipnja 1289. Ivanu i Leonardu, knezovima krčkim, vinodolskim i modruškim, dodijelio patronat nad Krbavskom i Senjskom biskupijom. ${ }^{29} \mathrm{U}$ to su vrijeme Krčki knezovi imali realan patronat i nad Krčkom biskupijom, premda im ga tek 1412. izričito potvrđuje kralj Sigismund. ${ }^{30}$ Postavljanje biskupa u trima spomenutim biskupijama, a zatim i dovođenje pojedinih crkvenih redova i podizanje njihovih crkava i samostana pokazuje kako su to pravo izvršavali Krčki knezovi/Frankopani.

Kad je riječ o franjevcima na području vlasti Krčkih knezova/Frankopana, vidljivo je da su oni od 1272. trajno zauzeti oko franjevačkog samostana u Senju, ${ }^{31}$ a od 1290. oko franjevačkog samostana u gradu Krku. ${ }^{32}$

Novo razdoblje $u$ širenju franjevaca $u$ hrvatskim krajevima $i$ na frankopanskim posjedima vezano je prvenstveno uz misijski rad hrvatskih franjevaca u Bosni. Valjalo je, naime, njihov misijski rad potvrditi i autentičnim franjevačkim životom. Tako su vrhovne crkvene vlasti odlučile da franjevci djelatni u Bosni uspostave zasebnu franjevačku pokrajinu u ovisnosti o generalu reda, tzv. vikariju. Stoga papa Benedikt XII. šalje generala franjevačkog reda

${ }^{26}$ S. PAVIČIĆ, 1942, 562.

${ }^{27}$ S. PAVIČIĆ, 1942, 563.

${ }^{28}$ Usp. M. BOGOVIĆ, 2001, 21-32; M. BOGOVIĆ, 2010.

${ }^{29}$ M. BOLONIĆ, 1971. - 1973., 233.

${ }^{30}$ M. BOLONIĆ, 1971. - 1973., 234-236; P. RUNJE, 2016, 15-28.

${ }^{31}$ Godine 1295. knez Leonard Krčki izdaje potvrdu darovnice Jakova iz Bribira senjskim franjevcima, iz koje se razabire da je on prihvatio patronat nad senjskim franjevcima. Knez Leonard je zajedno s bratom Dujmom podigao crkvu senjskim franjevcima (AHAZU, E. FERMENDŽIN, Acta Croatiae, rkp, sign. XV/24/16, 1).

${ }^{32}$ Usp. V. BRUSIĆ, 1932, 325-333. 
Gerarda Odonisa ugarsko-hrvatskom kralju Karlu Robertu, a zatim bosanskomu banu Stjepanu Kotromaniću. Gerard je 1340. osnovao Bosansku vikariju i na čelo joj stavio, kao vikara, svojeg pratitelja Peregrina Saksonca, koji je od 1349. do 1356. i bosanski biskup. ${ }^{33}$ Vikarija Bosne okupila je franjevačke misionare različitih narodnosti, ali je teret misijskoga djelovanja bio na franjevcima hrvatskog jezika. Svi su misionari zbog uspješnosti svojega djelovanja težili autentičnom franjevačkom životu u izričitom siromaštvu i s apostolskim djelovanjem. Rad vikarije podupire i ban Stjepan Kotromanić, pa moli papu da dopusti bosanskom vikaru 1347. osnivati samostane u mjestima gdje franjevci ili drugi redovnici nemaju svojih kuća. ${ }^{34}$ Za vikara Bartola Alvernskog (1366. - 1408.), koji je s prekidima gotovo četiri desetljeća vodio vikariju, proširila je vikarija Bosne svoju prisutnost i djelovanje preko granica srednjovjekovne Bosne. Dopustio je najprije papa Urban V. 1369. članovima vikarije sabirati i primati milostinju u Hrvatskoj i Ugarskoj, ${ }^{35}$ a zatim Grgur XI. (1370. - 1377.) 1372. godine podići izvan banovine Bosne jedanaest samostana. ${ }^{36}$ Bartol Alvernski je Bosansku vikariju izgradio kao prvu franjevačku upravnu jedinicu koja se u 14. stoljeću vratila strogom opsluživanju franjevačkog pravila - opservanciji. Njezina pojava i širenje podudara se s općim crkvenim naporima oko crkvene obnove nakon boravka papa u Avinjonu i u vremenu tzv. Zapadnog raskola (1378. - 1414.).

\section{Opservancija na posjedima Krčkih knezova/Frankopana}

U podršci crkvenih vlasti širenju Bosanske vikarije valja vidjeti i podržavanje opservanata. Ono se jedva događa u Hrvatskom primorju i njegovom zaleđu. Postupno prodiranje opservanata pokazuje činjenica da prva dva samostana u posjedu franjevaca na području Krbavske biskupije pripadaju dvjema različitim franjevačkim pokrajinama u 14. stoljeću. Samostan u Krbavi naseljavaju opservanti Bosanske vikarije. Taj samostan u to vrijeme nastanka ne podržavaju Krčki knezovi, već krbavski knezovi Kurjakovići, ${ }^{37}$ a Krčki knezovi su u to vrijeme uz franjevce provincije Dalmacije. Podržavaju ih u Krku i Senju, a predaju im također novopodignuti samostan u Modrušu, premda članovi te provincije slijede konzervativni oblik franjevačkog života, tzv. konventualizam. ${ }^{38}$

\footnotetext{
${ }^{33}$ AHAZU, E. FERMENDŽIN, Acta Croatiae, rkp, sign. XV/24/16, 349-353.

${ }^{34}$ D. MANDIĆ, 1968, 59, 227.

${ }^{35}$ E. FERMENDŽIN, 1892, 36.

${ }^{36}$ E. FERMENDŽIN, 1892, 38.

${ }^{37}$ Usp. I. BOTICA, 2011.

${ }^{38}$ M. BOLONIĆ, 1971. - 1973., 256-261.
} 
U tzv. Pizanskom popisu franjevačkih provincija i kustodija, ${ }^{39}$ a također i u popisu trogirskog franjevca Dujma koji se čuva u Dubrovniku, ${ }^{40}$ spominje se najkasnije 1393. da je provincija Sclavoniae ili Dalmatinska provincija imala četiri kustodije: dubrovačku, zadarsku ili splitsku, rapsku i istarsku. U rapskoj kustodiji bili su samostani u Rabu, na Cresu, u Krku, u Senju i u Modrušu. ${ }^{41}$

Opservancija je postala već potkraj 14. stoljeća čimbenikom franjevačkog raslojavanja gotovo u svim tradicionalnim provincijama Franjevačkog reda. Oko 1387. nastala je tako i unutar Dalmatinske provincije sv. Jeronima opservantska kustodija sv. Jeronima koja je okupljala one članove te provincije koji su se opredijelili za opservanciju. Izrijekom se ta kustodija prvi puta javlja 1436. u pismu generala franjevačkog reda Vilima de Casali koji spominje opservantske samostane na Pašmanu, Ugljanu i u Novigradu. ${ }^{42}$ Kustodija sv. Jeronima bila je u sastavu Bosanske vikarije, ${ }^{43}$ a za bosanskog vikara Jakova Markijskog (1435. - 1438.) pokazuje tendenciju uspostaviti samostalnu opservantsku vikariju sa simpatizerima opservancije među članovima Hrvatske (Dalmatinske) provincije, što papa Eugen IV. strogo zabranjuje 1437. pismom franjevcima u Dalmaciji i Bosni. ${ }^{44}$

U Bosanskoj vikariji trebao je Jakov Markijski 1438. nastaviti službu vikara i u sljedećemu trogodištu, ali su članovi vikarije pokazali prema njemu otpor i proglasili nezakonitom njegovu daljnju upravu u vikariji. Jakov je sve sudionike sastanka koji su se usprotivili njegovom upravljanju proglasio redovničkim odmetnicima, a oni su potražili utočište kod bivšega bosanskog vikara Ivana Korčulanina, tada varaždinskog biskupa, i kod knezova Frankopana u Senju ${ }^{45}$ Na pritužbu Jakova Markijskog nastala je prepiska između generala franjevačkog reda Vilima de Casali i Frankopana, u kojoj general traži da ovi protjeraju sve pribjegle franjevce iz Bosanske vikarije, osim dvojice koje mogu zadržati kao ispovjednike. ${ }^{46}$

Širenje opservancije u 15. stoljeću u Dalmatinskoj provinciji sve se više ubrzava sredinom tog stoljeća, pa papa Eugen IV. potvrđuje 1446. odluku o pridruživanju Bosanskoj vikariji pet samostana na Jadranu: sv. Franje u

\footnotetext{
${ }^{39}$ B. DE PISA, 1906, 555.

${ }^{40}$ M. BRLEK, 1954, 138.

${ }^{41}$ L. WADDINGUS, 1933, IX, 209, 210.

${ }^{42}$ D. MANDIĆ, 1968, 237.

${ }^{43}$ D. MANDIĆ, 1968, 236, 237.

${ }^{44}$ E. FERMENDŽIN, 1892, 160.

${ }^{45}$ E. FERMENDŽIN, 1892, 166.

${ }^{46}$ E. FERMENDŽIN, 1892, 168.
} 
Dubrovniku, sv. Sabine na Daksi kod Dubrovnika, sv. Križa kod Zadra, Sv. Nikole kod Kotora i sv. Eufemije u Kamporu na Rabu. ${ }^{47}$ Ti samostani ostali su samo godinu dana u sastavu Bosanske vikarije jer ih je već 5. prosinca 1447. papa Nikola V. svojom odlukom pridružio novoj i samostalnoj vikariji sv. Jeronima koju je, unutar provincije sv. Jeronima u Dalmaciji, osnovao generalni vikar franjevačkih opservanata Jakov Primadizzi. ${ }^{48}$ Isti je papa opozvao tu svoju odluku, ali time nije zaustavio nastojanja oko uspostave samostalnih opservantskih vikarija u Dalmaciji i na području Dubrovačke republike. Tako je najprije 1465. na teritoriju Dubrovačke Republike osnovana zasebna opservantska kustodija sa šest samostana ${ }^{49}$ a generalni kapitul opservanata 1467. dopustio je osnivanje i samostalne Dalmatinske vikarije, s time da ona zadrži i negdašnje samostane Bosanske vikarije na Ugljanu, Pašmanu i Sv. Katarine kod Zadra na mletačkom teritoriju, dok će Bosanska vikarija dobiti samostane na Krku (Košljun) i Trsatu u Hrvatskoj te u Hvaru na mletačkom području. ${ }^{50} \mathrm{U}$ tim suprotstavljanjima, najprije opservanata i konventualaca, a zatim samih opservanata bosanskog i talijanskog tipa, samostan u Krbavi 1448. je na čelu tzv. Krbavske kustodije. ${ }^{51}$ Godine 1462. spominje se kao njezin kustod Dionizije de Sclavonia, ${ }^{52}$ a 1464. toj je kustodiji doznačen novi samostan na Trsatu, zadužbina Martina Frankopana. ${ }^{53}$ Opravdano je uzeti u obzir činjenicu da su Frankopani u Senju, i to u senjskom samostanu, pružili utočište opservantima iz Bosanske vikarije. Tako su, očito, pomogli širenje opservancije među franjevcima u Senju i, konačno, prijelaz senjskog i modruškog samostana među opservantske samostane, što znači i pristupanje Bosanskoj vikariji. Senjski samostan 1473. pristupa Bosanskoj vikariji jer tada papa Siksto IV. dopušta taj čin senjskom samostanu, a pod prijetnjom ekskomunikacije zabranjuje Bosanskoj vikariji prihvaćati konventualske samostane bez dozvole najviših crkvenih vlasti. ${ }^{54}$

$\mathrm{Da}$ se prije 1473. senjski samostan nije nalazio u sastavu Bosanske vikarije, može se, također, razabrati iz zabilješke kako je te godine bivši vikar Bosanske vikarije Franjo Dubrovčanin, gvardijan senjskog samostana, prodao vinograd s odobrenjem novog bosanskog vikara Ljudevita. ${ }^{55} \mathrm{U}$ pismu pape Pavla

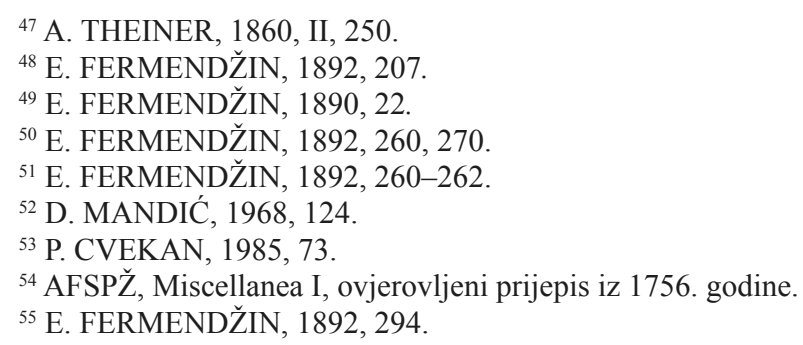


II. iz 1469. spominju se samostani Bosanske vikarije izvan područja koje su zaposjeli Osmanlije, a nema riječi o Modrušu i Senju. Tom zgodom spominju se sljedeći samostani: Krbava, Bihać, ${ }^{56}$ Otoka, Cetingrad, ${ }^{57}$ Trsat, Stjeničnjak ${ }^{58}$ i Bijela Stijena. ${ }^{59}$ Samostani na Trsatu, u Cetingradu i Stjeničnjaku bili su tada na području frankopanske vlasti. Povećao se ubrzo broj franjevačkih samostana

${ }^{56}$ Radoslav Lopašić spominje tradiciju da su u Bihaću već od 14. stoljeća franjevci imali samostan i crkvu sv. Marije (R. LOPAŠIĆ, 1890, 56). Sa sigurnošću se može pratiti povijest toga samostana tek od 1465. godine (E. FERMENDŽIN, 1892, 279), a 1506. je unutar Hrvatske ili Krbavske kustodije i ima crkvu posvećenu sv. Antunu i sv. Barbari (L. WADDINGUS, 1933, $\mathrm{XV}, 397)$. Pri uspostavi nove provincije Bosne-Hrvatske 1517. samostan u Bihaću je u sastavu Cetinske kustodije (F. GLAVINICH, 1648, 21). Godine 1578. nema više franjevaca u Bihaću, a 1586. preostale su od samostana gole zidine, ali fra Ivan Ivšić zajedno s bihaćkim građanima zamoli nadvojvodu Karla da pomogne povratak franjevaca u Bihać (R. LOPAŠIĆ, 1890, 57).

${ }^{57}$ Već se 1446. spominje crkva Blažene Djevice Marije u Cetingradu u Zagrebačkoj biskupiji kao mjesto osobitog štovanja Bogorodice (AHAZU, E. FERMENDŽIN, Acta Croatiae, rkp, sign. XV/24/16, 368). Franjevački samostan se spominje 1508. kad je župnik Ivan u Donjoj Kladuši zabranio, pod prijetnjom crkvenih kazni, vjernicima darivati tamošnje franjevce. Tom zgodom se spominje i gvardijan cetingradskog samostana Martin Bojničić (AHAZU, E. FERMENDŽIN, Acta Croatiae, rkp, sign. XV/24/16, 25). Razvaline negdašnjega franjevačkog samostana vidjele su se još u prvoj polovici ovog stoljeća u dvorištu i vinogradu kuće Mandić. U provinciji Bosni-Hrvatskoj je cetingradski samostan bio na čelu jedne kustodije pa su u njemu održani 1514., 1520., 1529., 1538., 1541. i 1544. provincijski kapituli (R. LOPAŠIĆ, 1895, 101-120).

${ }^{58}$ Stjeničnjak je od 1380. do 1479. frankopanski posjed, a od 1456. pripadao je Martinu Frankopanu. Još 1461. spominje se dobivanje osobitih oprosta u kapeli presv. Trojstva u Stjeničnjaku, a 1482. izričito se spominje samostan i crkva Tijela Kristovog (AHAZU, E. FERMENDŽIN, Acta Croatiae, rkp, sign. XV/24/16, 396, 444). Franjevcima u Stjeničnjaku sud je dosudio u posjed kuću koju im je ostavio 1501. svećenik Nikola, a gvardijan te zajednice Juraj iz Hrastovice primio je 1508. ostavštinu nekog građanina imenom Milša (AHAZU, E. FERMENDŽIN, Acta Croatiae, rkp, sign. XV/24/16, 37). Grgur Frankopan se 9. travnja 1545. odriče dijela desetine u korist franjevaca u Stjeničnjaku, kako su to činili prije njega njegovi prethodnici (AHAZU, Eusebius FERMENDŽIN, Acta Croatiae, rkp, sign. XV/24/16, 204). Godine 1556. je za provincijala Bosne Hrvatske bio izabran Franjo od Stjeničnjaka, a 1581. taj su samostan franjevci napustili prenijevši na Trsat i crkvena zvona. Danas se gradina Stjeničnjaka zove Rokunićeva gradina, a nalazi se nedaleko od naselja Gornji i Donji Sjeničak. U šumi Medvedaku ima ostataka ruševine stare crkve koju narod zove "Sveta žalost" i pripovijeda da je tu stajao franjevački samostan (R. LOPAŠIĆ, 1895, 267-290).

${ }^{59}$ Grad Bijela Stijena bio je srednjovjekovni posjed knezova Babonića, kasnije zvanih Blagajskih. Nalazi se istočno od Cazina i Ostrošca na brdu. Danas je ondje selo Stijena s muslimanskim stanovništvom. Blizu gradine su dvije crkvine s nešto ruševina. Po svoj prilici kod jedne od ovih crkvina nekoć je bio franjevački samostan koji se spominje i kasnije kod uspostave vikarije Bosne-Hrvatske, odnosno njezinoga proglašenja provincijom. Bijela Stijena je pala 1575. pod Osmanlije. To je bio i kraj franjevačkog samostana u tom gradu (R. LOPAŠIĆ, 1890, 120, 121; H. KEKEZ, 2016). 
na frankopanskom posjedu te popis samostana iz 1506. navodi, između ostalih, trsatsku kustodiju koja ima samostane na području frankopanske vlasti: ${ }^{60}$ Trsat, Senj, Cetingrad, Stjeničnjak, Modruš, Brinje ${ }^{61}$ i Zvonigrad. ${ }^{62}$ Tako je zamjetno porastao broj franjevačkih samostana na području frankopanske vlasti pa ih početkom 16. stoljeća ima deset: Senj, Modruš, Trsat, Krupa, Cetingrad, Stjeničnjak, Zrinj, Brinje, Zvonigrad i Hrastovica.

Drugi je pokazatelj prisutnosti i značenja franjevaca na području frankopanske državine niz franjevaca na biskupskim stolicama triju biskupija pod frankopanskim patronatom. U Senju su četiri franjevca biskupi tijekom 15. stoljeća: Ludovik iz Pirana (1436.), ${ }^{63}$ Andrija Drački (1443. - 1450.), ${ }^{64}$ Marko iz Rijeke (1457. - 1461.) ${ }^{65}$ i Pavao iz Bosne (1464. - 1489.). ${ }^{66}$ U Krku su dva franjevca bili biskupi u tomu razdoblju: Franjo Modrušanin (1444. - 1457.) i Nikola Valentini Krčanin (1457. - 1484.). ${ }^{67}$ Uz Franju Modrušanina, koji je 1460. pristao na prijenos sijela krbavske biskupije iz Krbave pod vlašću Kurjakovića $\mathrm{u}$ frankopanski Modruš ${ }^{68}{ }^{\mathrm{u}}$ krbavskoj biskupiji je također bio biskup franjevac imenom Antun (1484.). ${ }^{69}$

\section{Osmanlijska osvajanja i početak novoga vijeka}

Brojni franjevački samostani na području frankopanskih posjeda i niz franjevaca na biskupskim stolicama triju biskupija pod patronatom Frankopana tijekom 15. stoljeća ukazuju na naglo širenje franjevaca na tom području u drugoj polovici 15. i početkom 16. stoljeća. Za ovo povećanje broja franjevaca i porast njihova značenja presudna je promjena u geopolitičkoj povijesti

${ }^{60}$ L. WADDINGUS, 1933, XV, 397, 398.

${ }^{61}$ Sačuvano je pismo pape Pija II., datirano 17. svibnja 1463., u kojem stoji da je Martin Frankopan od najviših crkvenih vlasti zatražio dopuštenje podići samostane na Trsatu i u Brinju. Papa je to dopustio odredivši da u te samostane treba postaviti takve franjevce koji će se odlikovati revnošću i s kojima će biti zadovoljan Martin Frankopan (E. FREMENDŽIN, 1892, 253).

${ }^{62}$ Zvonigrad je do 1432. bio u vlasti Nelipića, a tada je vlasništvo Frankopana do 1509. kada ga je stekao lvan Karlović (G. SZABO, 1920, 210). Ostaci gradine leže danas na osamljenom brijegu u dolini rijeke Zrmanje. Samostan se spominje i u vremenu diobe Bosanske vikarije na Bosnu Srebreničku i Bosnu-Hrvatsku (F. GLAVINICH, 1648, 21).

${ }^{63}$ M. SLADOVIĆ, $1856,49$.

${ }^{64}$ M. SLADOVIĆ, $1856,99$.

${ }^{65}$ C. EUBEL, 1914, II, 237.

${ }^{66}$ M. SLADOVIĆ, 1856, 100.

${ }^{67}$ C. EUBEL, 1914, 287.

${ }^{68}$ C. EUBEL, 1914, 136, 263.

${ }^{69}$ I. ČRNČIĆ, 1867, 105. 
Bosne, nastala njezinim padom pod osmansku vlast i širenjem opservancije među franjevcima u hrvatskim krajevima na štetu konventualskog ogranka Franjevačkog reda. Očito je da u tom cjelokupnom zbivanju nije neznatna uloga samih Frankopana, osobito nakon uspostave Vikarije Bosne-Hrvatske. Ona je osnovana u slijedu događaja nakon pada Bosanskog kraljevstva 1463. godine. Prilike u Bosanskoj vikariji bivale su svakim danom sve teže. Osmanlije su iz Bosne stalno navaljivale na hrvatske slobodne krajeve i svake je godine sve više samostana Bosanske vikarije dolazilo pod njihovu političku vlast, osim ako ih ne bi Osmanlije razorile u ratnim okršajima. Ugovor bosanskog kustoda Anđela Zvizdovića sa sultanom Mehmedom II. i sultanova povelja, tzv. Ahdnama, tražili su lojalnost franjevaca prema novim gospodarima. No, u slobodnim krajevima upravo su franjevci pozivali na otpor i oporbu prema osvajačima. Osmanske su vlasti ubrzo posumnjale u lojalnost podaničkih franjevaca koji su bili u čestim susretima i pod istom redovničkom upravom s onima iz samostana Bosanske vikarije u još neosvojenim krajevima. Tako su društveno-politički razlozi sve više tražili podjelu Bosanske vikarije na dva dijela: na dio pod Osmanlijama i na dio pod ugarsko-hrvatskim kraljem. Neprestani ratovi samo su pospješili diobu, do koje je došlo početkom 16 . stoljeća. Odlukom vrhovne uprave Franjevačkog reda razdijeljena je 29. lipnja 1514. Bosanska vikarija na dvije nove pokrajine - na vikariju Bosnu Srebreničku (Srebrenu) pod osmanskom vlašću i vikariju Bosnu-Hrvatsku, koja će okupiti u svom sastavu samostane Bosanske vikarije na području koje još nisu osvojile Osmanlije. ${ }^{70}$

Vikarija Bosna-Hrvatska je 1517. postala provincijom pod istim imenom i tada je brojila četiri kustodije: cetinsku, trsatsku, krbavsku i grebensku. ${ }^{71} \mathrm{Na}$ području frankopanske vlasti nova je provincija imala dvanaest samostana: Senj, Trsat, Modruš ${ }^{72}$ Krupu, Cetingrad, Stjeničnjak, Zrinj, Brinje, Zvonigrad, Hrastovicu, Slunj ${ }^{73}$ i Knin. ${ }^{74}$ Velik je dio od ukupnog broja od 29 samostana

${ }^{70}$ E. FERMENDŽIN, 1892, 307.

${ }^{71}$ F. GLAVINICH, 1648, 20-22.

${ }^{72}$ M. KRUHEK, 2008.

${ }^{73}$ Samostan u Slunju spominje se 1510. kad je udovica Uršula Landar učinila oporuku i u njoj zatražila da bude pokopana u crkvi sv. Bernardina kod franjevaca opservanata u Slunju (AHAZU, E. FERMENDŽIN, Acta Croatiae, rkp, sign. XV/24/16, 43). Samostan u Slunju bio je nastanjen franjevcima do 1578., kad su ga oštetile Osmanlije za jedne svoje provale. Crkva Presvetog Trojstva, a ne više sv. Bernardina, postala je župnom crkvom (G. SZABO, 1920, 164).

${ }^{74} \mathrm{Knin}$ su Osmanlije okupirale već 1520. godine, a 1522. su ga razorile (V. GREIDERER, 1777, II, 148, 149). 
novouspostavljene provincije pod patronatom Frankopana, što nužno nameće slutnju da bi teško bilo osnovati tu novu franjevačku pokrajinu bez izričite potpore Frankopana. Koliko je značajna bila uloga te velikaške porodice 1514. kod diobe Bosanske vikarije i kako je ona bila važno uporište novoj vikariji Bosni Hrvatskoj, kao i samom opservantskom pokretu u hrvatskim krajevima, pokazuje povelja generalnog vikara franjevačkih opservanata knezu Mihajlu Frankopanu Slunjskom. Generalni vikar opservanata Kristofor da Forli izdao je 27. lipnja 1514. u samostanu S. Maria degli Angeli povelju kojom zahvaljuje Mihovilu Frankopanu za iskazana dobročinstva te ga proglašava skrbnikom svojega reda u Bosni i dionikom svih milosnih zasluga franjevačkog bratstva. Iste je povlastice Kristofor udijelio Mihovilovoj ženi Barbari Rozgon i sinovima Jurju, Matiji i Petru. ${ }^{75} \mathrm{U}$ toj povelji, dakle, jasno se razabire uloga Frankopana u širenju franjevaca opservanata na prostor zapadne Hrvatske, premda su i franjevci konventualske struje u to doba prisutni na području krbavske biskupije i frankopanske vlasti. ${ }^{76}$

Osmanlije su poslije 1463. stalno prodirali iz Bosne prema zapadnim područjima Hrvatske. Godine 1468. došli su do Senja, poharali Modruš i zarobili mnoštvo ljudi. Sljedeće godine ponovno su pod Senjom, a prošli su preko Krbave i Like opustošivši opet Modruš. Osmanski prodori slijedili su jedan za drugim i stalno ugrožavali živote stanovništva na području ratnih pohoda. Kad je 1493. hrvatska vojska doživjela težak poraz na Krbavskom polju, modruški biskup napustio je središte biskupije i preselio se u grad Novi u Vinodolu, a krbavska biskupija, kao samostalna crkvena strukturalna jedinica, našla se u borbi za opstanak. Nakon što su 1527. Osmanlije osvojile Krbavu i Modruš, Krbavska biskupija doživjela je svoj kraj. Sličnu sudbinu doživjela je i franjevačka provincija Bosna-Hrvatska. Njezini članovi napuštaju samostane na pograničnom području. Neki se nastanjuju po plemićkim kurijama, ali im to zabranjuje crkvena vlast. ${ }^{77}$ Do sredine 16. stoljeća Bosna-Hrvatska izgubila je najveći dio svojih samostana. U Modruškoj biskupiji sačuvala je samostan na Trsatu, a u Senjskoj biskupiji samostan u Senju. ${ }^{78}$

Velikaška obitelj Frankopana sredinom prve polovice 16. stoljeća više nije bila u stanju realno vršiti patronat niti nad krbavskom biskupijom niti nad

${ }^{75}$ R. LOPAŠIĆ, $1892,328$.

${ }^{76}$ Franjevcima konventualcima pripadao je Pavao Modrušanin (Modruš, druga polovica 15. st. - 22. VIII. 1531.). Priredio je za tisak 1528. u Veneciji glagoljski misal. U kolofonu misala na posljednjoj stranici sebe naziva konventualom (P. RUNJE, 1993, 227-330).

${ }^{77}$ AHAZU, E. FERMENDŽIN, Acta Croatiae, rkp, sign. XV/24/16, 458.

${ }^{78}$ F. GLAVINICH, 1648, 22. 
franjevačkom provincijom Bosnom-Hrvatskom. Ratovi s Osmanlijama i druge nedaće umanjile su zamjetno njezinu društvenu i materijalnu moć. Tako su na ostacima frankopanske državine ostali ostaci Krbavske biskupije i provincije Bosne-Hrvatske. Ime krbavske biskupije sačuvali su senjski biskupi, među kojima su u 16. stoljeću četvorica franjevci. ${ }^{79}$ Provincija Bosna-Hrvatska spasila se od propasti šireći se na područje sjeverozapadne Hrvatske i Slovenije, ali je samo djelomično sačuvala svoje povijesno ime pod nazivom Hrvatsko-kranjska provincija sv. Križa ${ }^{80}$

\section{Zaključak}

Nastanak i razvoj franjevačkog samostana u Senju, od kraja 13. do početka 16. stoljeća, vezan je uzširi crkveni i društveno-politički kontekst srednjovjekovne Hrvatske i njezina neposredna susjedstva, kao i događanja na općem europskom i crkvenom planu. Prvenstveno su četiri razloga širenja franjevačke prisutnosti na istočnoj obali Jadrana i unutrašnjosti u srednjem vijeku. Prvi je naglo širenje Reda za života sv. Franje, kada nastaju prvi samostani na hrvatskoj obali Jadrana. Krajem 13. stoljeća započinje franjevačka misija u Bosni i sučeljavanje s heterodoksnim kršćanstvom u Dalmaciji i Bosni, ali i uklapanje franjevaca u feudalni društveni i crkveni sustav, kada se njihovi samostani pojavljuju na području sjevernog Jadrana i u unutrašnjosti. Novi poticaj jakom širenju franjevaca na prostoru Hrvatske i Bosne dat će pojava opservantskog pokreta $\mathrm{u}$ drugoj polovici 14. stoljeća, osobito bosanskog tipa koji će se iz Bosne prenijeti u Dalmaciju, užu Hrvatsku i Slavoniju. Naposljetku, kao četvrti razlog širenja franjevaca u srednjem vijeku jest potiskivanje konventualaca i uspostavljanje ustrojstva franjevaca opservanata. Uz to, franjevci su od osnutka početkom 13. stoljeća do kraja 15. stoljeća nositelji obnove u Crkvi. U 13. stoljeću oni su odgovor na društvene i crkvene prilike toga vremena, dok opservancija $u$ 14. i 15. stoljeću predstavlja unutrašnji franjevački odgovor na potrebu strožeg opsluživanja Pravila sv. Franje, ali i odgovor na potrebe obnove Crkve nakon Avinjonskog sužanjstva i Velikog zapadnog raskola.

Samostan u Senju izvrstan je primjer na koji su se način na lokalnoj razini odražavali procesi od širega značenja unutar srednjovjekovne Europe. Osnovan

${ }^{79}$ C. EUBEL, 1914, III, 299; M. SLADOVIĆ, 1856, 103-104; AHAZU, E. FERMENDŽIN, Acta Croatiae, rkp, sign. XV/24/16, 344.

${ }^{80}$ Godine 1688. utjecaj slovenskih franjevaca bio je toliko jak da je provincija izgubila ime Bosna-Hrvatska i nazvana provincijom sv. Mihaela u Kranjskoj. No, nakon otpora hrvatskoga dijela te provincije 1708. dobila je novo ime Hrvatsko-kranjska provincija sv. Križa. 
u vremenu drugoga velikog franjevačkog širenja prema sjevernom Jadranu i u unutrašnjost Hrvatske, samostan u Senju bio je znak da je sam grad postao važno gradsko središte s visokim stupnjem urbanog života 13. stoljeća, kao i to da ima važnu ulogu u daljnjim nastojanjima Crkve oko suzbijanja utjecaja heterodoksnog kršćanstva u Bosni i Dalmaciji. On je također i pokazatelj inkorporiranosti crkvenih institucija u feudalni sustav srednjovjekovne Hrvatske, što se očituje u tome da samostan osniva velikaška obitelj Frankopana, koji s vremenom dobivaju pravo patronata nad mnogim crkvenim institucijama na velikim područjima svoje vlasti. Povijest senjskog samostana u 14. i početkom 15. stoljeća pokazuje kako se ovdje također prelamaju povijesni procesi koji su na razini Reda, Crkve i političkog spektra šireg prostora izvan frankopanske državine našli odjeka i u samom životu senjskih franjevaca. Promjena frankopanske politike koja se od podržavanja konventualaca polako okreće, osobito pojavom opservanata bosanskog tipa prema opservanciji, dovela je do napuštanja konventualskog načina življenja u senjskom samostanu i prihvaćanja opservancije. Ovaj proces samo je dio puno širih procesa na razini opće Crkve i unutar srednjovjekovnog Hrvatskog i Bosanskog kraljevstva. Na primjeru senjskog samostana također se može vidjeti i velika promjena s početka 16. stoljeća koja je dovela do raspada svih srednjovjekovnih institucija na spomenutom prostoru. Potiskivanje konventualaca i organiziranje opservantske uspravne strukture istovremena je s prodorom Osmanlija na prostor srednjovjekovne Hrvatske, što će naposljetku dovesti do sloma dotadašnjeg oblika feudalnog sustava srednjovjekovne Hrvatske. To se najbolje očituje slabljenjem i nestankom prava patronata Frankopana nad crkvenim institucijama na svojim posjedima. Smanjivanjem njihova teritorija zbog osmanlijskih osvajanja slabit će njihova politička i društvena moć, a sami franjevci doživjet će slom. Tako će se sredinom 16. stoljeća njihova prisutnost na području sjevernog Jadrana svesti na samostane na Trsatu i u Senju, dok će se na otocima očuvati srednjovjekovni samostani podijeljeni na konventulaske i opservantske u sastavu dvaju novih provincija, dvaju novih grana Franjevačkog reda.

\section{Literatura}

\section{Izvori}

Arhiv Hrvatske akademije znanosti i umjetnost: AHAZU, Eusebius FERMENDŽIN, Acta Croatiae, rkp, sign. XV/24/16

Arhiv franjevačkog samostana u Požegi: AFSPŽ, Miscellanea I 
BF:

Bullarium Franciscanum sive Romanorum Pontificum constitutiones, epistolae, diplomata tribus ordinibus Minorum, Clarissarum, Poenitentium a seraphico patriarcha Sancto Francisco institutis ab eorum originibus ad nostra usque tempora concessa, tomus V, Romae, 1898.

Bullarium Franciscanum sive Romanorum Pontificum constitutiones, epistolae, diplomata tribus ordinibus Minorum, Clarissarum, Poenitentium a seraphico patriarcha Sancto Francisco institutis ab eorum originibus ad nostra usque tempora concessa, tomus III, Romae, 1765.

CD:

Codex diplomaticus Regni Croatiae, Dalmatiae et Slavoniae, V., Tadija SMIČIKLAS (ur.), Zagreb, 1907.

Codex diplomaticus Regni Croatiae, Dalmatiae et Slavoniae, VII., Tadija SMIČIKLAS (ur.), Zagreb, 1909.

Codex diplomaticus Regni Croatiae, Dalmatiae et Slavoniae, XI., Tadija SMIČIKLAS (ur.), Zagreb, 1913.

Codex diplomaticus Regni Croatiae, Dalmatiae et Slavoniae, XII., Tadija SMIČIKLAS (ur.), Zagreb, 1914.

Codex diplomaticus Regni Croatiae, Dalmatiae et Slavoniae, XIII., Tadija SMIČIKLAS, Mirko KOSTRENČIĆ, Emilij LASZOWSKI (ur.), Zagreb, 1915.

Codex diplomaticus Regni Croatiae, Dalmatiae et Slavoniae, XIV., Tadija SMIČIKLAS, Mirko KOSTRENČIĆ (ur.), Zagreb, 1934.

Codex diplomaticus Regni Croatiae, Dalmatiae et Slavoniae, XV., Tadija SMIČIKLAS, Mirko KOSTRENČIĆ, Jakov STIPIŠIĆ (ur.), Zagreb, 1976.

Eusebius FERMENDŽIN, Chronicon observantis Provinciae Bosnae Argentinae ordinis S. Francisci, Starine JAZU, 22, Zagreb, 1890.

Eusebius FERMENDŽIN Acta Bosnae potissimum ecclesiastica cum insertis editorum documentorum regestis ab anno 925 usque ad annum 1752, Zagreb, 1892.

Luca WADDINGUS, Annales Minorum seu trium ordinum a S. Francisco institutorum, tomus VIII, Ad Claras Aquas (Quaracchi), 1932.

Luca WADDINGUS, Annales Minorum seu trium ordinum a S. Francisco institutorum, tomus IX, Ad Claras Aquas (Quaracchi), 1933.

Luca WADDINGUS, Annales Minorum seu trium ordinum a S. Francisco institutorum, tomus XV, Ad Claras Aquas (Quaracchi), 1933.

\section{Knjige i članci}

Vitomir BELAJ, Razvoj franjevaštva na području Hrvatske franjevačke provincije sv. Ćirila i Metoda, Franjevci Hrvatske provincije sv. Ćirila i Metoda, Zagreb, 1992. 
Vitomir BELAJ - Bonaventura DUDA - Emanuel HOŠKO, Zatočenici gesla "Mir i dobro", Mir i dobro. Umjetničko i kulturno nasljeđe Hrvatske franjevačke provincije sv. Ćirila i Metoda, Zagreb, 2000.

Ante BIRIN, Knez Nelipac i hrvatski velikaški rod Nelipčića (disertacija), Filozofski fakultet u Zagrebu, Zagreb, 2006.

Mihovil BOLONIĆ, Samostani i patronat u senjskoj biskupiji, Senjski zbornik, 5, Senj, 1971. - 1973., 219-318.

Mile BOGOVIĆ, Prijelazno stoljeće senjske crkve, Senjski zbornik, 17, Senj, 1990, 69-92.

Mile BOGOVIĆ, Hrvatsko glagoljsko tisućljeće, Senjski zbornik, 25, Senj, 1998, 15-28.

Mile BOGOVIĆ, Povijest biskupija Senjske i Modruške ili Krbavske, Fontes: izvori za hrvatsku povijest, 7/1, Zagreb, 2001, 21-32.

Mijo BRLEK, Tri rukopisna kodeksa iz dubrovačke prošlosti, Anali Historijskog instituta JAZU u Dubrovniku, 3, Dubrovnik, 1954, 135-147.

Mile BOGOVIĆ, Otočac od spomena na Bašćanskoj ploći do biskupijskog sjedišta u XV. stoljeću. Povodom 550. obljetnice osnutka Otočke biskupije (1460. - 2010.), Otočac, 2010.

Ivan BOTICA, Krbavski knezovi u srednjem vijeku (disertacija), Filozofski fakultet u Zagrebu, Zagreb, 2011.

Vladislav BRUSIĆ, Dolazak franjevaca na Košljun, Bogoslovska smotra, 20, Zagreb, 1932, 325-333.

Josip BURIĆ, Biskupija senjska i modruška u XVIII. stoljeću, Zagreb, 2002.

Paškal CVEKAN, Trsatsko svetište Majke milosti i franjevci njeni čuvari, Trsat, 1985.

Ivan ČRNČIĆ, Najstarija poviest krčkoj, osorskoj, rabskoj, senjskoj i krbavskoj biskupiji, Roma, 1867.

Bartholomaeus DE PISA, De conformitate vitae B. Francisci, Analecta Franciscana, 4, Romae, 1906, 513-590.

Conrad EUBEL, Geschichte der oberdeutschen (Strassburger) Minoriten-Provinz / mit Unterstützung der Görresgesellschaft herausgegeben von P. Konrad Eubel, Würzburg, 1886.

Conradus EUBEL, Hierarchia catholica medii aevi, II, Monasterii, 1914.

Daniele FARLATI, Illyricum sacrum, IV, Venetiis, 1769.

Daniele FARLATI, Illyricum sacrum, VI, Venetiis, 1800.

Josip FRANČIŠKOVIĆ, Crkva sv. Franje u Senju, Bogoslovska smotra, 19, Zagreb, 1931, 411-423.

Tomislav GALOVIĆ, Latinski epitafi, Putovima Frankopana. Frankopanska baština u Primorsko - goranskoj županiji, Rijeka, 2018, 257-258.

Ante GLAVIČIĆ, Njemačko bombardiranje Senja, Senjski zbornik, 10/11, Senj, 1983/1984, 341-354.

Franciscus GLAVINICH, Historia Tersattana: raccolta dalle antiche, e moderne historie, annali, e traditioni, Udine, 1648. 
Vigili GREIDERER, Germania franciscana seu Chronicon geographo-historicum ordinis s.p. Francisci in Germania, I, Oeniponte, 1777.

Zorislav HORVAT, Pregled sačuvanih nadgrobnih ploča Krčkih knezova Frankopana, Senjski zbornik, 32, Senj, 2005, 25-56.

Franjo Emanuel HOŠKO, Franjevci u kontinentalnoj Hrvatskoj kroz stoljeća, Zagreb, 2000 .

Franjo Emanuel HOŠKO, Franjevci i poslanje Crkve u kontinentalnoj Hrvatskoj, Zagreb, 2001.

Hrvoje KEKEZ, Pod znamenjem propetog lava - povijest knezova Babonića do kraja 14. stoljeća, Zagreb, 2016.

Vjekoslav KLAIĆ, Krčki knezovi Frankapani, Zagreb, 1901.

Nada KLAIĆ, Kada i kako su knezovi Krčki stekli Modruš i Vinodol?, Vjesnik historijskih arhiva u Rijeci i Pazinu, sv. XVI, Rijeka, 1971, 129-168.

Ivan KUKULJEVIĆ-SAKCINSKI, Nadpisi sredovječni i novovjeki na crkvah i javnih $i$ privatnih sgradah u Hrvatskoj i Slavoniji, Zagreb, 1891.

Milan KRUHEK, Srednjovjekovni Modruš: Gradovi knezova Krčkih - Frankopana i biskupa Krbavsko - modruške biskupije, Ogulin, 2008.

Ozren KOSANOVIĆ, Potknežin i vikar kao službenici knezova Krčkih u Senju (od 1271. do 1469. godine), Zbornik Odsjeka za povijesne znanosti Zavoda za povijesne $i$ društvene znanosti HAZU, 31, Zagreb, 2013, 1-20.

Ozren KOSANOVIĆ, Državina Krčkih knezova - Vinodol, Senj i Krk od početka 14. stoljeća do 1420. godine (disertacija), Filozofski fakultet u Zagrebu, Zagreb, 2012.

Radoslav LOPAŠIĆ, Bihać i Bihaćka krajina: mjestopisne i poviestne crtice, Zagreb, 1890.

Radoslav LOPAŠIĆ, Oko Kupe i Korane: mjestopisne i poviestne crtice, Zagreb, 1895.

Dominik MANDIĆ, Franjevačka Bosna, Roma, 1968.

Predrag MARKOVIĆ, Mramorni reljefi mletačke radionice Bon u Senju i krčki knezovi Frankopani, Radovi instituta za povijest umjetnosti, 30, Zagreb, 2006, 9-28.

Luigi PALOMES, Dei Frati Minori e delle loro denominazioni, Palermo, 1897.

Carlo PASCONI, Triumphus Coronatae reginae Tersactensis, signis, prodigiis ubique nitentis, Venetiis, 1731 .

Stjepan PAVIČIĆ, Bužani, Hrvatska enciklopedija, III, Zagreb, 1942, 562.

Petar RUNJE, Prve vijesti o franjevcima u gradu Krku, Krčki zbornik, 74, Krk, 2016, 15-28. (Iz rukopisne ostavštine mr. sc. fra Petra Runje (1938. - 2014.), za tisak priredio Tomislav Galović)

Petar RUNJE, Izdavač i nakladnici glagoljskog Misala Pavla Modrušanina iz godine 1528., Slovo - časopis Staroslavenskog instituta u Zagrebu, 41-43, Zagreb, 1993, 227-240.

Manoilo SLADOVIĆ, Poviest biskupiah senjske i modruške ili krbavske, Trieste, 1856.

Gjuro SZABO, Sredovječni gradovi u Hrvatskoj i Slavoniji, Zagreb, 1920. 
Stanko Josip ŠKUNCA, Povijesni pregled franjevačke Provincije sv. Jeronima u Dalmaciji i Istri, Pula-Zadar, 2006.

Pavao TIJAN, Vodič po Senju i okolici, Senj, 1931.

Augustin THEINER, Vetera monumenta historica Hungariam sacram illustrantia, II, Romae, 1860.

Ferdinando UGHELLI, Italia Sacra, tomus VIII, Romae, 1721.

Marijan ŽUGAJ, S. Francesco in Croazia e la protoprovincia Croata. Roma, 1982.

Marijan ŽUGAJ, I Conventi delli Minori Conventuali tra i Croati delle origini fino al 1500, Roma, 1989.

\section{THE FRANCISCANS IN SENJ - FROM THE CONVENTUAL TO THE OBSERVANTS}

\section{Summary}

The Franciscan monastery in Senj was founded in the $13^{\text {th }}$ century when the Counts of Krk, later the Frankopans, became the administrators of the town. In that time the Franciscans were the coordinators of the restoration of the Church and their presence in the towns showed that a certain environment came to a certain degree of urbanity. On the other hand, the Franciscans in towns represented an element which contributed to the development of town life in all circles. The article follows the period from the founding of the Franciscan monastery in Senj up until the beginning of the $16^{\text {th }}$ century. The history of Senj monastery is presented in the context of wider ecclesiastical and socio-political relationships, on the European and local level. The influence of the aristocratic family of the Counts of Krk/Fankopans on the spread of the Franciscans and the transition of individual monasteries from conventual life to the observant life, in this case the monastery in Senj, is shown through processes at the level of the general Church which were reflected in the area of central and southeast Europe. Therefore, the theme of the paper is to show how in the context of the socio-political circumstances there was a transition from conventualism to observation amongst Senj's Franciscans. Likewise, the role of the Counts of Krk/Frankopans and their right of patronage in the local Church as the fundamental coordinators of the social and political life over the large area of their rule in the context of feudal relations of mediaeval Croatia is valorised. In the example of the monastery in Senj it can be seen how the changes and processes over three centuries influenced the role of the monastery in the life of the defined space, changes in the very life of the Franciscans who abandoned the more conservative conventual direction and accepted the strict servicing of the Rules - observation, the influence of feudal lords on the ecclesiastical and political life of the place which they ruled, and all within the framework of events on the general European and ecclesiastical level and in a place which formed the immediate hinterland of their possession. The beginning of the $16^{\text {th }}$ century and the incursions of the Ottomans destroyed all the mediaeval institutions in the region of Frankopan rule. The monastery in Senj survived the Ottoman devastation and with the weakening of the Frankopans' influence on the social, political and ecclesiastical events in the area it entered a new period of a new age.

Keywords: Senj, Franciscans, monastery, Counts of Krk/Frankopans, conventualists, observants, Bosna Srebrena, Bosna Hrvatska, Ottomans 